\title{
Barrier Properties of Electroplating Nickel Layer for Copper Metallization in Silicon Solar Cells
}

\author{
You Ren Cheng ${ }^{1}$, Wen Jauh Chen ${ }^{1, *}$, Keisuke Ohdaira ${ }^{2}$ and Koichi Higashimine ${ }^{2}$ \\ ${ }^{1}$ Graduate School of Materials Science, National Yunlin University of Science and Technology, \\ Douliu, Yunlin, Taiwan. \\ ${ }^{2}$ Japan Advanced Institute of Science and Technology, 1-1 Asahidai, Nomi, Ishikawa 923-1292, Japan. \\ *E-mail: chenwjau@yuntech.edu.tw
}

doi: $10.20964 / 2018.12 .23$

Received: 15 August 2018 / Accepted: 20 September 2018 / Published: 5 November 2018

\begin{abstract}
In this work, a thin nickel layer was deposited on textured (001) silicon by an electroless plating method. The as-deposited nickel film samples were annealed at $500^{\circ} \mathrm{C}$ in an $\mathrm{Ar} / \mathrm{H}_{2}$ atmosphere for 10 min to form nickel silicide. Ni surface etching was done in $\mathrm{HNO}_{3}$ to remove unreacted nickel. This substrate is designed as ta-Si. Afterward, the Ni layer with various thicknesses and the $1.5 \mu \mathrm{m}$ thick $\mathrm{Cu}$ film were deposited on ta-Si by an electroplating technique to form the $\mathrm{Cu} / \mathrm{Ni} / \mathrm{ta}-\mathrm{Si}$ structure. The $\mathrm{Cu} / \mathrm{Ni} / \mathrm{ta}-\mathrm{Si}$ samples were annealed at various temperature for 10 minutes in an annealing furnace. The $\mathrm{Cu} / \mathrm{Ni} / \mathrm{ta}-\mathrm{Si}$ samples were defined using the following: $\mathrm{x}$-ray diffractometer (XRD), scanning electron microscope (SEM), and scanning transmission electron microscope (STEM). For the $\mathrm{Cu} / \mathrm{Ni}(120$ $\mathrm{nm}$ )/ta-Si samples, the $\mathrm{Cu}_{3} \mathrm{Si}$ particles develop from an annealing temperature of $400^{\circ} \mathrm{C}$. This revealed that electroplating a thin $\mathrm{Ni}$ layer can act as a diffusion barrier against $\mathrm{Cu}$ at around $400^{\circ} \mathrm{C}$.
\end{abstract}

Keywords: Textured silicon; Electroplating; Solar cells; Diffusion barrier

\section{$\underline{\text { FULL TEXT }}$}

(C) 2018 The Authors. Published by ESG (www.electrochemsci.org). This article is an open access article distributed under the terms and conditions of the Creative Commons Attribution license (http://creativecommons.org/licenses/by/4.0/). 